Geological Society of London. In these the patient examination of the strata and the marshalling of the palæontological evidence linked up the geology of North Wales and the Irish coast. The first of the series dealt with the faunal zones of the RushSkerries Carboniferous Section, Co. Dublin, and further papers considered the strata at Malahide and at Ballycastle, Co. Antrim. The fine paper on the geology of Great Orme's Head (1925) led to the award of the Sc.D. degree. The Irish Academy published a similar contribution on the Carboniferous Rocks of Hook Head, Co. Wexford (1930). His papers gave detailed descriptions of fossils, notably of corals.

In 1934 Smyth succeeded Joly in the University chair of geology, which he occupied until his death. He devoted himself, unremittingly, to his teaching, and to the improvement of the Geological Museum and Department. $\mathrm{He}$ was never happier than when taking his students and overseas colleagues on geological expeditions-and few university cities have more varied geological interest close at hand than has Dublin. After a gap, occasioned by his teaching duties and illnesses, came "The Carboniferous System of North County Dublin" (Geol. Soc., 1950) and "A Viséan Cephalopod Fauna in the Rush Slates" (Roy. Irish Acad., 1951). A clear lecturer, a sympathetic teacher, loyally devoted to his University, a true friend - there are many who mourn his loss. W. R. G. Atkrins

\section{Mr. C. E. N. Bromehead}

Cyril Edward Nowill Bromehtad, formerly of the Geological Survey, died on December 4. He was born at York on January 8, 1885, and was educated at Marlborough and at Merton College, Oxford. $\mathrm{He}$ joined the Geological Survey of Great Britain in 1909 and was assigned as his first major task the 6-inch survey of a large part of the London area. With Henry Dewey he devised the present nomenclature of the gravel-terraces of the Thames Valley, and he became an authority on the geology and early history of London and particularly on the buried tributaries of the Thames such as the Fleet and Ty Bourne.

In the First World War he served in Flanders and was severely wounded. He returned to the Geological Survey in time to take part in explorations in Derbyshire which led in 1919 to the drilling of Britain's first oil-well at Hardstoft.

In 1922 he was appointed district geologist in charge of Yorkshire. Employing techniques of stratigraphical palæontology then being devised by W. S. Bisat, Sir Arthur Trueman and W. B. Wright, he and his staff became experts on the Upper Carboniferous rocks. In fifteen years his unit made a detailed revision of most of the coalfield and its borders-an area of nearly 1,000 square miles-and sent to the press the relevant maps and memoirs as well as a new edition of the memoir on the "Concealed Coalfield of Yorkshire and Nottinghamshire". These publications have proved invaluable in subsequent developments of the coalfield.

In 1935 Bromehead took charge of geological work in Southern England, where mapping was proceeding in Kent. For much of the next ten years, however, his duties were connected with the Second World War, and throughout this time his knowledge and experience were always at his colleagues' service. $\mathrm{He}$ relinquished some of his responsibilities in 1945 and retired in 1949 .
During this last period his interest in the origins of geology and related arts (he-was a founder-member of the Society for History of Science) was revealed in two presidential addresses to the Geologists' Association on the early history of practical geology and mining in Britain, and in papers on antiquarian subjects-'eagle-stones', loadstones, 'murrhine', early water-supply and museums - in which a high order of classical scholarship was delightfully blended with geology. He also wrote on oil, reservoir-dams and fluorosis.

Profoundly influenced in his youth by what was then known as the 'Oxford Movement', Bromehead practised religion with characteristic thoroughness. $\mathrm{He}$ is remembered with affection by the many who experienced his kindliness and culture, his wisdom and, not least, his firmness in moments of crisis.

WILFRID EDWARDS

\section{Mr. R. S. Styles and Mr. F. W. Campbell}

Ronald Stephen Styras and Frederick William Campbell, who were attached to the Division of Radiophysics of the Commonwealth Scientific and Industrial Research Organization, Australia, were killed in an aircraft accident near Sydney on October 27 while engaged on research in cloud physics and natural rain formation.

Styles and Campbell were on a routine flight in an R.A.A.F. Dakota fitted for cloud 'probing' using microwave radar and special instruments designed in the Division of Radiophysics for observing cloud temperature, liquid-water content and cloud droplet spectra. The aireraft had been investigating clouds over the sea and reported that it was descending from $6,000 \mathrm{ft}$. to $2,000 \mathrm{ft}$. through low cloud and heavy rain preparatory to returning to base. It failed to report at the next check-point, and an intensive emergency search was immediately organized. Oil, wreckage and a half-inflated rubber dinghy were found a short distance out to sea, and some items recovered were identified as belonging to personnel on the aircraft; all on board, including an R.A.A.F. crew of four, were killed.

Mr. Styles was born in Sydney, Now South Wales, in 1926. At the University of Sydney he took a course combining physics and electrical engineering. $\mathrm{He}$ graduated with the double degree of B.Sc. and B.E. and joined the Radiophysics Division as a research officer in March 1948. His initial work concerned radio aids to aircraft navigation, to which he made valuable contributions. He was then transferred to work on rain and cloud physics, and his obvious ability and enthusiasm soon led to his taking a major part in airborne observations of natural rain. His observations of the development of non-freezing clouds to give rain are of particular interest. He also contributed significantly to the development of instruments in this field and displayed a marked ability for organizing, implementing and analysing results in this difficult field of research. He leaves a widow and an infant son.

Mr. Campbell was born in 1915, at Norseman, Western Australia. After successfully completing a radio course at Perth Technical College in 1934, he spent the pre-war years as a radio engineer in Perth. During the Second World War he served with the Royal Air Force, rising to the rank of squadron leader. $\mathrm{He}$ undertook specialized radio and radar courses at Prestwick, Great Malvern and elsewhere, 